\title{
Evolution of Syariah Law Curriculum at Faculty of Law, UKM: A Way Forward
}

\author{
Ahmad Azam Mohd Shariff ${ }^{1}$ \\ Safinaz Mohd Hussein² \\ Tengku Noor Azira Tengku Zainudin ${ }^{3}$ \\ Asma Hakimah Ab Halim ${ }^{4}$ \\ Nazura Abdul Manap 5 \\ Ramalinggam Rajamanickam 6 \\ Mohd Azhan Yahya ${ }^{7}$ \\ Fatimah Yusro Hashim ${ }^{8}$

\begin{abstract}
${ }^{1}$ Associate Professor, Faculty of Law, Universiti Kebangsaan Malaysia; aazam@ukm.edu.my
${ }^{2}$ Associate Professor, Faculty of Law, Universiti Kebangsaan Malaysia; finas@ukm.edu.my

${ }^{3}$ Associate Professor, Faculty of Law, Universiti Kebangsaan Malaysia; tna@ukm.edu.my

${ }^{4}$ Lecturer, Faculty of Law, Universiti Kebangsaan Malaysia; hakimah@ukm.edu.my

${ }^{5}$ Associate Professor, Faculty of Law, Universiti Kebangsaan Malaysia; nazura@ukm.edu.my

${ }^{6}$ Lecturer, Faculty of Law, Universiti Kebangsaan Malaysia; rama@ukm.edu.my

${ }^{7}$ Lecturer, Faculty of Law, Universiti Kebangsaan Malaysia; mohdazhanyahya@ukm.edu.my

${ }^{8}$ Lecturer, Faculty of Law, Universiti Kebangsaan Malaysia; wardatun@ukm.edu.my
\end{abstract}

Doi:10.5901/mjss.2016.v7n3p50

\section{Abstract}

Since its establishment in 1984, the Faculty of Law, Universiti Kebangsaan Malaysia (hereinafter refered to as UKM) has always strived towards producing law graduates who are equally competent in both civil as well as syariah laws. In keeping abreast with current syariah legal developments, the syariah law curriculum has truly evolved over the years. The Law Faculty is now offering syariah law courses which suit the current demand of the syariah legal industry. It is thus extremely important to ensure the survival of these syariah courses at the faculty. One sure way of ensuring their survival is to ensure that their curriculum remain current and relevant as well as in tandem with the latest development in the syariah legal industry. In assessing the above-mentioned evolution of the Syariah Law Curriculum, this paper relies on articulated arguments which is qualitative in nature. All findings in this paper rest on the methodologies of critical and content analysis conducted on the relevant materials gathered on the subject.

Keywords: syariah law curriculum, syariah legal developments, faculty of law, UKM

\section{Introduction}

The Faculty of Law, UKM was established on 1st February 1984 with the aim to produce graduates trained as lawyers and legal professionals in various fields of civil and syariah laws. The LLB programme has, over the years, prepared students to be civil and syariah lawyers, capable of serving in various capacities, among others, as independent lawyers or as officers in the judiciary or the attorney general's office. This is in line with the mission of the Faculty of Law to produce learned legal professionals of outstanding qualities inspired by our national aspirations (Rohimi, 1994). Driven by the aim to produce execellent graduates in both civil and syariah laws, the Faculty has always strived towards enhancing the syariah curriculum. The faculty realized the importance of having a sound curriculum which stays relevant and current. This is to ensure that the syariah courses keep abreast with current developments in the syariah legal industry. It is hoped that by this way, UKM's law graduates remain competitive and able to meet the needs and demands of the industries (A. Halim, 1996; Faridah, 2014). 


\section{The Research: Objectives and Methodologies Used}

The research bears some important objectives. First of all, it examines the development of all syariah courses offered at the Law Faculty UKM. Secondly, the research identifies the challenges that have surfaced throughout the evolving years of the inception of the syariah curriculum at the faculty. Thirdly, this research offers suggestions and improvements on the syariah curriculum in ensuring success of production of law graduates who perfectly fit into the syariah legal fraternity and industry.

Methodology-wise, this research adopts a qualitative design. Research methodologies such as critical and content analysis as well as field observation are used for data verifications. The methodologies of critical and content analysis are used in obtaining information on the evolvement of syariah courses and curriculum at the Law Faculty UKM. During the field study, the methodology of observation is also adopted in assessing the course contents of all syariah courses in ensuring that the syariah curriculum stays relevant in the face of new challenges.

\section{Faculty of Law UKM: Several Evolutions on the Syariah Curriculum}

During the yesteryears, the faculty only offered very limited number of syariah law courses. The courses offered were:

Year 1 - Introduction to Islamic Law

- Islamic Civilisation and Nationhood

Year 2 - Islamic Jurisprudence- Family, Succession and Commercial Transaction

Year 3 - Islamic Jurisprudence- Crime and the Administration of Law

Year 4 - No Syariah law courses on offer

It was not until 1993 that the faculty reviewed its law curriculum. Then, the Syariah courses were revamped for content and focus enhancement. Starting from the 1993/1994 academic session, more specific and detailed syariah courses were being offered. Clearly, the syariah courses were designed to keep abreast with the development in the syariah legal fraternity at that point of time when several new syariah enactments were enacted by several states' administrations (A. Halim, 1996; Rohimi, 1994). Among the new revamped syariah courses offered then were:

Year 1 - UK 1113 Introduction to Islamic Law I (first semester)

- UK 1123 Introduction to Islamic Law II (second semester)

Year 2 - UK 2113 Islamic Jurisprudence- Family, Succession and Commercial Transaction I (first semester)

- UK 2123 Islamic Jurisprudence- Family, Succession and Commercial Transaction II (second semester)

Year 3- UK 3093 Islamic Jurisprudence- Crime and the Administration of Law I

(first semester. The code was later changed to UK 3113 in the 1994/95 session)

- UK 3103 Islamic Jurisprudence- Crime and the Administration of Law II

(second semester. The code was later changed to UK 3123 in the 1994/95)

Year 4 - There was no compulsory syariah course on offer. However, UK 4593 Principles of Islamic Jurisprudence I and Principles of Islamic Jurisprudence II were offered as one of the electives courses for semester 1 and 2 respectively.

In the year of 1997, the Law Faculty performed its second revamp and modifications on the syariah courses. The faculty had taken a bold step in its effort to enhance the syariah curriculum at the faculty. It involved an offer of a new course of more practical orientation, and division of an existing course into 2 compulsory courses more specificity content-wise. The courses of UK 4112 Law of Evidence and Procedures of Syariah Court I and UK 4122 Law of Evidence and Procedures of Syariah Court II began to be offered as compulsory courses for the final year students. The courses were aimed to expose students to aspects of evidence and procedures of civil and criminal trials at syariah court. With the introduction of the said courses, the intention of the faculty to produce skillful graduates in areas of syariah law became clear (A. Haji, 2013; Faridah, 2014).

Meanwhile, another important revamp was on UK 2113 Islamic Jurisprudence-Family, Succession and Commercial Transaction I; and UK 2123 Islamic Jurisprudence-Family, Succession and Commercial Transaction II. These two courses were then redivided into 2 more specific courses. As a consequence, the course of UK 2113 Islamic Family Law became a compulsory course for Year 2, semester 1, while Islamic Succession was a compulsory course in Year 2 ,semester 2 (Faridah, 2014).

At the same time, new courses of Muamalat I and Muamalat II were introduced as compulsory courses for Year 3, semesters 1 and 2. The UK 3113 Islamic Criminal Law I and UK 3123 Islamic Criminal Law II which previously were compulsory courses for Year 3 semesters 1 and 2 were given new codes. The new codes were UK 2113 Islamic Criminal Law I dan UK 2123 Islamic Criminal Law II and both were compulsory courses for Year 2, semesters 1 and 2 respectively 
(Ahmad, 2013).

The aforementioned development was a major evolution toward enhancement and consolidation of the syariah curriculum at the Faculty. It was a clear indication that the faculty was moving forward in ensuring that its syariah curriculum was always in synct with current developments. It was indeed a noble effort from the faculty to ensure the marketability of its law graduates in the face of healthy competitions from graduates from the other law schools in Malaysia (A. Haji, 2013; Hakimah, 2014). The evolution could be witnessed from the table below:

\begin{tabular}{|r|l|}
\hline Year of Study & Syariah Courses at the Faculty of Law UKM \\
\hline Year 1, Semester 1 & UK 1113 Introduction to Islamic Law I \\
\hline Semester 2 & UK 1123 Introduction to Islamic Law II \\
\hline Year 2, Semester 1 1 & $\begin{array}{l}\text { UK } 2113 \text { Islamic Criminal Law I } \\
\text { (Previously UK 3113 was a compulsory course for Year 3 sem 1) } \\
\text { UK 2133 Islamic Family Law }\end{array}$ \\
\hline Semester 2 2 & $\begin{array}{l}\text { UK 2123 Islamic Criminal Law II } \\
\text { (Previously UK 3123 a compulsory course for Year 3 sem 1) } \\
\text { UK 2143 Islamic Law of Succession }\end{array}$ \\
\hline Year 3, Semester 1 & UK 3132 Muamalat I \\
\hline Semester 2 & UK 3142 Muamalat II \\
\hline Year 4, Semester 1 & UK 4112 Law of Evidence and Procedures of Syariah Court I \\
\hline Semester 2 & UK 4122 Law of Evidence and Procedures of Syariah Court II \\
\hline
\end{tabular}

\section{Challenges Faced by the Syariah Curriculum in the Face of the Revamp on the Civil Law Curriculum}

There was a major revamp on the law programme curriculum in the academic session of $2000 / 01$. This was due to inclusion of many new courses to maintain the relevancy of the law curriculum to meet the prevalent development and demands. The outcome was that several syariah courses were revamped and consolidated from 2 semester courses into a single course taught in 1 semester (Faridah, 2014).

For Year 1, the pair of Introduction to Islamic Law courses were combined and consolidated to become a single course taught in Year 1, semester 2 and was coded as UK 1113. For Year 2, the Islamic Criminal Law I and II were combined and consolidated to be a single one semester course taught in Year 2, semester 1 and was given a new code of UK 2113. As far as Year 2 was concerned, the syariah courses of Islamic Family Law, previously taught in semester 1, and Islamic Succession, previously taught in semester 2, were combined and consolidated to become a single course for one semester in Year 2, being coded as UK 2133 (Hakimah, 2014).

Meanwhile, the courses of Muamalat I and Muamalat II, each offered during semester 1 and 2 of the Year 3 resepctively, were combined and consolidated to become a single course. The new Muamalat course was taught in one semester and was given a new code UK 3133. Although there were reduction of units and consolidation of both courses, a positive development also happened. The offer of a new elective course for the third year students in the name of UK 4637 Islamic Banking Law and Takaful was seen to be in line with the need of the times where Islamic banking industry and takaful are very much in the mainstream of national banking and takaful industries. The new course further added academic values to the law programme at the faculty (Ahmad, 2013; Faridah, 2014).

The flipside of the added values, however, was that the syariah curriculum had compromised in terms of values and effectiveness due to reductions of units and compression of the 3 aforementioned-courses. Nevertheless, it was an unavoidable sacrifice that had to be undertaken to sustain the relevance of law programme at the Faculty as a whole (Yusro, 2013). The summary of the new syariah set up was as follows:

\begin{tabular}{|r|l|}
\hline \multicolumn{1}{|c|}{ Year of Study } & Syariah course at Faculty of Law UKM \\
\hline Year 1, Semester 1 & No Syariah course on offer \\
\hline Semester 2 & UK 1113 Introduction to Islamic Law \\
\hline Year 2, Semester 1 & UK 2113 Islamic Criminal Law \\
& UK 2133 Islamic Family Law and Succession (Group A) \\
\hline Semester 2 & UK 2133 Islamic Family law and Succession (Group B) \\
\hline Year 3, Semester 1 & UK 4673 Islamic Banking Law and Takaful (Elective Course) \\
\hline Semester 2 & UK 3133 Muamalat \\
& UK 4673 Islamic Banking Law and Takaful (Elective Course) \\
\hline Year 4, Semester 1 & UK 4112 Law of Evidence and Procedures of Syariah Court I \\
\hline Semester 2 & UK 4122 Law of Evidence and Procedures of Syariah Court II \\
\hline
\end{tabular}




\section{The Syariah Curriculum at Law Faculty of UKM: Consolidation of Existing Courses}

The next evolution of the syariah curriculum was the consolidation of the law programme and the syariah curriculum in particular at the Faculty.

A major evolution occured when Islamic Banking Law and Takaful, previously an elective course, was later elevated as a compulsory course for Year 3 students. It was given a new code of UK 3152/UK 3153 Islamic Banking Law and Takaful. It has since been taught in Year 3, semester 1. This reflects the Faculty's serious endeavour to consolidate and upgrade the syariah law programme while ensuring that the development of the law programme was always in line with the rapid growth of Islamic banking and takaful industries in Malaysia (A. Haji, 2013; Yusro, 2013).

Another major enhancement was when the syariah course of UK 3133 Muamalat, previously taught in Year 3, was then offered as a compulsory course for Year 2, semester 2. A new code of UK 2122/UK 2153 Muamalat was given to it. The new course of UK 3162/UK 3163 Islamic Jurispridence was also introduced as a new compulsory course for year 3 , semester 2 students.

The introduction of 3152/UK 3153 Islamic Banking Law and Takaful and UK 3162/UK 3163 Islamic Jurisprudence as compulsory courses in Year 3, semester 1 amd 2 simultaneously consolidated the syariah curriculum at the Faculty overall (Faridah, 2014). This newly revamped syariah set up could clearly be seen in the following table:

\begin{tabular}{|c|l|l|}
\hline \multicolumn{2}{|c|}{ Year of Study } & \multicolumn{2}{l|}{ Syariah courses at Faculty of Law UKM } \\
\hline Year 1, & Semester 1 & No Syariah course on offer \\
\hline & Semester 2 & UK 1113 Introduction to Islamic Law \\
\hline Year 2, & Semester 1 & UK 2113 Islamic Criminal Law \\
& UK 2133 Islamic Family Law and Succession \\
\hline & Semester 2 & UK 2153 Muamalat \\
\hline Year 3, & Semester 1 & UK 3153 Islamic Banking Law and Takaful \\
\hline & Semester 2 & UK 3163 Islamic Jurisprudence \\
\hline Year 4, & Semester 1 & UK 4133 Law of Evidence and Procedures of Syariah Court I \\
\hline & Semester 2 & UK 4143 Law of Evidence and Procedures of Syariah Court II \\
\hline
\end{tabular}

\section{Syariah Curriculum: Summary of Its Development at the Law Faculty}

The syariah courses and their curriculum had really survived some tough challenges since its inception as part of the law curriculum at Faculty of Law, UKM in 1984. The following tables illustrated the development of the Syariah curriculum for almost 30 years from 1984 to February 2014:

Table 1: The First Syariah Curriculum at Faculty of Law, UKM

\begin{tabular}{|c|l|}
\hline Year of Study & Syariah Courses at the Faculty of Law, UKM \\
\hline Year 1 & $\begin{array}{l}\text { Introduction to Islamic Law } \\
\text { Islamic Civilisation and Nationhood }\end{array}$ \\
\hline Year 2 & Islamic Jurisprudence- Family, Succession and Commercial Transaction \\
\hline Year 3 & Islamic Jurisprudence- Crime and the Administration of Law \\
\hline Year 4 & No Syariah courses on offer \\
\hline
\end{tabular}

Table 2: Syariah Curriculum at Faculty of Law, UKM: The First Modification

\begin{tabular}{|r|l|}
\hline \multicolumn{1}{|c|}{ Year of Study } & Syariah courses at the Faculty of Law ,UKM \\
\hline Year 1, Semester 1 & UK 1113 Introduction to Islamic Law I \\
\hline Semester 2 & UK 1123 Introduction to Islamic Law II \\
\hline Year 2, Semester 1 & UK 2113 Islamic Jurisprudence- Family, Succession and Commercial Transaction I \\
\hline Semester 2 & UK 2123 Islamic Jurisprudence- Family, Succession and Commercial Transaction II \\
\hline Year 3, Semester 1 1 & $\begin{array}{l}\text { UK } 3093 \text { Islamic Jurisprudence- Crime and the Administration of Law I } \\
\text { (Code changed to UK 3113 in 1994/95 session) }\end{array}$ \\
\hline Semester 2 2 & $\begin{array}{l}\text { UK 3103 Jurispruden Islam- Islamic Jurisprudence- Crime and the Administration of Law II (Code } \\
\text { changed to UK 3123 in 1994/95 session) }\end{array}$ \\
\hline Year 4, Semester 1 & No compulsory course on offer. UK 4593 Principles of Islamic Jurisprudence I- Elective course \\
\hline Semester 2 & No compulsory course on offer. UK 4603 Principles of Islamic Jurisprudence II- Elective course \\
\hline
\end{tabular}


Table 3: Syariah Curriculum at Faculty of Law, UKM: The First Major Revamp

\begin{tabular}{|r|l|}
\hline \multicolumn{1}{|l|}{ Year of Study } & Syariah Courses at the Faculty of Law, UKM \\
\hline Year 1, Semester 1 & UK 1113 Introduction to Islamic Law I \\
\hline Semester 2 & UK 1123 Introduction to Islamic Law II \\
\hline Year 2, Semester 1 1 & $\begin{array}{l}\text { UK 2113 Islamic Criminal Law I (previously UK } 3113 \text { was compulsory course for Year } 3 \text { sem 1) } \\
\text { UK 2133 Islamic Family Law }\end{array}$ \\
\hline Semester 2 & $\begin{array}{l}\text { UK 2123 Islamic Criminal Law II (previously UK } 3123 \text { was compulsory course for Year 3 sem 2) } \\
\text { UK 2143 Islamic Succession Law }\end{array}$ \\
\hline Year 3, Semester 1 & UK 3132 Muamalat I \\
\hline Year 4, Semester 2 1 & UK 3142 Muamalat II \\
\hline Semester 2 & UK 4112 Law of Evidence and Syariah Court Procedures I \\
\hline
\end{tabular}

Table 4: Syariah Curriculum at Faculty of Law, UKM: The Second Revamp in Face of Industry's Developments

\begin{tabular}{|r|l|}
\hline \multicolumn{1}{|c|}{ Year of Study } & Syariah courses at the Faculty of Law, UKM \\
\hline Year 1, Semester 1 & No Syariah course on offer \\
\hline Semester 2 & UK 1113 Introduction to Islamic Law \\
\hline Year 2, Semester 1 & $\begin{array}{l}\text { UK 2113 Islamic Criminal Law } \\
\text { UK 2133 Islamic Family Law and Succession (Group A) }\end{array}$ \\
\hline Semester 2 & UK 2133 Islamic Family Law and Succession (Group B) \\
\hline Year 3, Semester 1 & UK 4673 Islamic Banking Law and Takaful (Elective course) \\
\hline Semester 2 & UK 3133 Muamalat \\
UK 4673 Islamic Banking Law and Takaful (Elective course)
\end{tabular}

Table 5: Syariah Curriculum at Faculty of Law, UKM: The Era of Consolidation

\begin{tabular}{|r|l|}
\hline \multicolumn{1}{|c|}{ Year of Study } & Syariah courses at the Faculty of Law, UKM \\
\hline Year 1, Semester 1 & No Syariah course on offer \\
\hline Semester 2 & UK 1113 Introduction to Islamic Law \\
\hline Year 2, Semester 1 & UK 2113 Islamic Criminal Law \\
& UK 2133 Islamic Family Law and Succession \\
\hline Semester 2 & UK 2153 Muamalat \\
\hline Year 3, Semester 1 & UK 3153 Islamic Banking Law and Takaful \\
\hline Semester 2 & UK 3163 Islamic Jurisprudence \\
\hline Year 4, Semester 1 & UK 4133 Law of Evidence and Syariah Court Procedures I \\
\hline Semester 2 & UK 4143 Law of Evidence and Syariah Court Procedures II \\
\hline
\end{tabular}

Looking at the above brief outlook on the significant development of the syariah curriculum at the Faculty of Law, UKM, it is important to prepare ahead in ensuring its presence, significance and survival in the face of several future possible legal developments in the country.

\section{The Importance of Syariah Curriculum Survival at the Faculty of Law, UKM}

It is indeed important to ensure the significance and survival of the syariah curriculum at the faculty in the face of several possible challenges and legal developments in the country. The syariah academic staffs at the faculty have made the following stand in ensuring its survival namely:

1. There is an urgent need to defend and maintain the existing framework of the syariah curriculum at the Faculty. After undergoing various developments and weathering many challenges, curriculum has reached content maturity. The curriculum should not be any more be tampered with further reductions. On the contrary, the syariah curriculum shoud be fortified and enhanced.

2. The UK 3153 Islamic Banking Law and Takaful should be maintained as a compulsory course for Year 3. The reasons are as follow: 
i. The course is in line with the needs of mainstream Islamic Banking and Takaful industries in Malaysia. Rapid development of the Islamic financial market make it all the more crucial to maintain the course as compulsory. The course reflects the Faculty being in tune with the mainstream financial market development. Reducing the course to an elective status is counterproductive and degenerative.

ii. The UK 3153 Islamic Banking Law and Takaful carry a rebranded status of the LLB programme at the Faculty. This is a valuable identity for LLB programme marketing strategy. The Faculty can promote and capitalise on this edge of its LLB programme compared to those of other higher learning institutions.

iii. The UK 3153 Islamc Banking Law and Takaful as a compulsory course has given the much needed edge by the UKM law graduates. In a random survey among the graduates (chambering students or working legal practitioners), $68 \%$ admitted that the course helped them obtained favourable perception of the interviewers in their chambering or job interviews.

Evidently, the Islamic Banking Law and Takaful as a compulsory course in the LLB programme had attracted attention of the financial market players. These advantages should be maintained to prepare the graduates to compete with those of other higher learning institutions. The course has significantly been contributing toward increasing marketability of UKM law graduates.

a. The status quo of the existing percentage of courses that already meet the requirement should be maintained.

b. Need to defend the content of professional course proven to be able to prepare students for excellence in the field. The Islamic Banking Law and Takaful that have brought prestige and marketability of graduates to the Faculty should be maintained.

3. The syariah teaching team is committed towards improving and consolidating course contents of all syariah courses at the Faculty to meet the industry requirements. Among steps that have been taken are as follows:

i. Improvement of the contents of the basic syariah principles in each courses through various efforts and consolidation process.

ii. Reviews of teaching and learning and other aspects related to MQA requirements.

iii. Submision of course contents to relevant industries, bodies/institutions for review, evaluation and comments to ensure the courses remain relevant and meet the indudtry requirements.

iv. Ensure each syariah courses inculcates the elements of problem-based learning (PBL).

v. Enhancement of knowledge and skills among lecturers of syariah courses.

\section{Conclusion}

In the face of more future challenges in the syariah legal industry, it is thus extremely important to ensure the survival, sustainability as well as relevancy of all syariah courses and their curriculums at Faculty of Law, UKM. Thus, the teaching team for the syariah courses are committed to ensure the value and quality of syariah curriculums are enhanced through regular monitoring, modification and improvement. This is crucial to ensure that the syariah curriculum remain relevant and enhance the marketability of the LLB graduates from Faculty of Law, UKM.

\section{References}

A. Halim Muhammad. (1996). Syariah Courses at the Law Faculty UKM: An Overview of Its Significance and Development. Paper Presented at Faculty of Law Retreat Programme. Riviera Resort, Melaka, 1996.

A. Haji B. (2013). Bachelor of Law Programme at Faculty of Law UKM: A curriculum Review. Retreat Programme. Cheringin Hill Resort, Janda Baik, Pahang, 2013.

Ahmad A. Mohd Shariff. (2013). Teaching and Learning of Syariah Evidence Course: A UKM's Law School Experience. International Conference on Teaching and Learning. Universiti Sains Islam Malaysia (USIM), Nilai, Negeri Sembilan. October 2013.

A. Hakimah A. Halim. (2014). Review of LL.B Curriculum at UKM's Faculty of Law: A Report on Syariah Courses Content Review. Workshop on Law Curriculum Review. Port Dickson, Negeri Sembilan. May 2014.

Faridah A. Jalil. (2014). Law Curriculum Review by Faculty of Law UKM: Proposed Amendments and Revamps. Workshop on Undergraduates Teaching and Learning. Glory Beach Resort, Port Dickson. 21st-24th February 2014.

F. Yusro Hashim. (2013). Teaching and Learning Islamic Family Law: The Experience of Faculty of Law UKM. International Conference on Teaching and Learning. Universiti Sains Islam Malaysia (USIM), Nilai, Negeri Sembilan. October 2013.

Rohimi Shapie. (1994). Law Curriculum at UKM: An Overview and Projection. Paper Presented at Faculty of Law Retreat Programme. Bayu Beach Resort, Negeri Sembilan. October 1994. 